\title{
Monoclonal antibody-mediated cytotoxicity against rat Beta cells detected in vitro does not cause Beta-cell destruction in vivo
}

\author{
B.Ziegler, S. Lucke, E. Köhler, B. Hehmke, M. Schlosser, S. Witt, W. Besch and M.Ziegler \\ Institute of Diabetes "Gerhardt Katsch" Karlsburg, Ernst-Moritz Arndt-University of Greifswald, FRG
}

\begin{abstract}
Summary. Two monoclonal Beta-cell surface antibodies M10H6 und K14D10 were obtained by fusion of spleen cells of $\mathrm{Balb} / \mathrm{c}$ mice with the myeloma cell line $\mathrm{P}_{3} 0$. The monoclonal antibody M10H6 was induced by immunization with rat insulinoma cells finally boostered with disintegrated rat islets, whereas the K14D10 was generated after immunization with porcine proinsulin. Both monoclonals belong to the $\mathrm{IgG}_{2 \mathrm{~A}}$ isotype and were screened with insulin-producing rat insulinoma cells by an indirect immunofluorescence test as well as by a cellular enzyme linked immunosorbent assay. In addition to the cell surface binding on living Beta cells the monoclonals react with islets on cryostat sections of rat pancreas. The anti-islet cytotoxic potential of these monoclonals was measured by ${ }^{51} \mathrm{Chromium}$-release in the presence of complement or Fc-receptor bearing leucocytes using ${ }^{51} \mathrm{Chro}-$ mium-labelled rat islet cells as target. Both antibody secret-
\end{abstract}

ing hybridomas were propagated in syngeneic mice resulting in high levels of islet cell surface antibodies in ascites and sera from the recipient. High anti-islet cytotoxicity was mediated by ascites fluid, but no mouse developed hyperglycaemia. Furthermore, the repeated injections of the monoclonals into rats did not exert a diabetogenic action and failed to reduce the pancreaticinsulin content although the attraction of the K14D10 to the pancreatic islets in vivo could be demonstrated. We conclude that islet cell surface antibody-mediated Beta-cell lysis in vitro may not be relevant to Beta-cell destruction in vivo.

Key words: Monoclonal islet cell surface antibodies (mcICSA), anti-islet cell toxicity, application in vivo, pancreatic insulin content, rat.
There is now abundant evidence that Type 1 (insulin-dependent) diabetes mellitus results from the destruction of pancreatic Beta cells by mononuclear cells of the immune system. Even in the preclinical phase anti-islet cell cytoplasmic antibodies (ICA) can be detected [1]. Recently glutamic acid decarboxylase has been discovered to be the prominent Beta-cell specific cytoplasmic $64 \mathrm{kD}$ autoantigen in Type 1 diabetes [2]. Islet cell surface antibodies (ICSA) preferentially bind to Beta cells [3] and mediate anti-islet toxicity in vitro [4], but their role in the destruction of Beta cells in vivo remains unclear. The production of monoclonal ICSA (mc-ICSA) and their propagation by growing hybridomas in syngeneic mice offers the possibility of investigating the significance of ICSA for Betacell destruction.

In the present study mc-ICSA were generated by different immunization procedures; their islet cell toxic potential by activation of complement or Fc-receptor bearing leucocytes was investigated in vitro using rat islet cells or islets as targets and in vivo after application into rats, as well as in hybridoma bearing mice with high levels of ICSA in their circulation. In addition to the binding of the monoclonals as ICSA on living rat islet and insulinoma cells, their reactivity in vitro and in vivo as ICA was detected on cryostat sections of rat pancreas after in vitro incubation and $24 \mathrm{~h}$ after in vivo application into rats.

\section{Materials and methods}

\section{Animals and cells}

$\mathrm{Balb} / \mathrm{c}$ mice were supplied by the Institute of Biomodels (Berlin, FRG) and were allowed to acclimatize for at least one week before use in experimental work. NEDH rats were from our breeding colony, originally supplied by Dr. A. Lernmark, Hagedorn Research Laboratory (Gentofte, Denmark). Cultured rat insulinoma cells (RIN) are derived from this rat strain [5]. The RIN cell line was cultured in standard medium RPMI 1640 containing $7.5 \%$ heat-inactivated fetal calf serum supplemented with $2 \mathrm{mmol} / \mathrm{l}$ glutamine, $1 \mathrm{mmol} / \mathrm{l}$ pyruvate, $145 \mathrm{mg} / \mathrm{l}$ streptomycin, $50 \mathrm{mg} / \mathrm{l}$ gentamycin and passaged every week by detachment in the presence of $0.02 \%$ EDTA and $0.05 \%$ trypsin. Normal rat and mouse islets and islet cells were isolated after collagenase digestion of pancreata from 10 14-day-old animals by standard procedure as detailed previously [6]. 


\section{Measured variables}

The pancreatic insulin and glucagon content of rats and mice was estimated by radioimmunoassay after homogenization in phosphoric acid/ethanol and overnight storage at $4^{\circ} \mathrm{C}[7,8]$. Blood samples were taken from the retro-orbital sinus or by heart catheterisation under ether anaesthesia after aspiration of the intraperitoneal ascites fluid. Plasma glucose was assayed by the glucose oxidase method in a Beckman glucose analyzer (Beckman Instruments, Fullerton, Calif., USA). The ICSA level in the ascites and serum of mice bearing mcICSA-producing hybridomas and in serum of rats after injection of monoclonal ICSA was detected by indirect immunofluorescence technique using RIN cells [9].

\section{Hybridoma generation and antibody screening}

Immune response was induced by five i.p. injections of $50 \mu \mathrm{g}$ porcine proinsulin into a female 8-week-old Balb/c mouse. For the first injection proinsulin solution was emulsified in complete Freund's adjuvant followed by four further i.p. injections of proinsulin emulsified in incomplete Freund's adjuvant given on days $14,28,55$ and 86 . Four days before fusion the mouse was boostered with $100 \mu \mathrm{g}$ proinsulin on day 105 . Another mouse received $100 \mu \mathrm{l}$ complete Freund's adjuvant on day 0 followed by i.p. injections of $5 \times 10^{6} \mathrm{RIN}$ cells on days $1,14,42,54$. The last boosters were performed with 350 ultrasonically disintegrated neonatal rat islets on days $185,186,187$ in $154 \mathrm{mmol} / 1 \mathrm{NaCl}$ followed by fusion on day 188 according to the method of Lane et al. [10] and as detailed previously [11]. After 2 weeks during which the hybrid cells were grown semiconfluently, the medium was removed and assayed for antibodies reacting with the surface of living rat insulinoma cells tested by indirect immunofluorescence as described previously [12-13] or by ELISA using desiccated RIN cells $\left(5 \times 10^{4}\right.$ per sample) as target [14]. Antibody positive microcultures were cloned and recloned by limiting dilution and grown in culture medium or as ascites tumours in $\mathrm{Balb} / \mathrm{cmice}$ primed with pristane 10 days before i. p. injection of $2 \times 10^{5}$ hybridoma cells into each mouse [15]. The immunoglobulin concentration in hybridoma supernatants and in the ascites fluids as well as the isotypes were determined by ELISA standard procedures using goat antimouse immunoglobulin class and subclass-specific antibodies $[13,14]$.

In addition, the reaction of certain mc-ICSA was detected on cryostat sections of rat and mouse pancreas using the APAAP (alkaline phosphatase anti-alkaline phosphatase) method [16]. Consistent with the RIN cell donor strain, in this assay pancreata of NEDH rats were used as targets [5]. Every incubation step of the assay was performed for $30 \mathrm{~min}$ at room temperature. The cryostat sections were incubated with culture supernatants containing mcICSA followed by incubation with rabbit anti-mouse immunoglobulin (Dakopatts, Glostrup, Denmark) diluted 1:20 and with APAAP (Dakopatts) diluted 1:25. The bound antibodies were visualized using the chromogen substrate naphthol-AS-bi-phosphate. Cross-reaction of mc-ICSA with insulin and glucagon was examined by radioimmunoassay [17].

\section{Beta-cell binding of $m c-I C S A$}

Purified rat islet Beta and non-Beta cells were prepared by autofluorescence-activated cell sorting according to a previously described procedure [18]. The isolated cells $\left(6 \times 10^{4}\right.$ in $\left.200 \mu \mathrm{l}\right)$ were incubated with the mc-ICSA and irrelevant monoclonals for $60 \mathrm{~min}$. The cells were washed twice and resuspended in rhodamine-labelled swine anti-mouse immunoglobulin antiserum, incubated for $30 \mathrm{~min}$, washed and finally fixed in $4 \%$ (volume/volume) formaldehyde. The cell preparations were analysed by fluorescence-activated cell sorting (FACS) in a Facstar (Sunnyvale, Calif., USA) equipped with a 2025-05 Argonlaser (Spectra Physics, Mountain View, Calif., USA) to quantify the percentage of fluorescent cells [19].

\section{Investigation of in vivo effects of $m c-I C S A$}

To examine the binding of the mc-ICSA in the islets after in vivo application, NEDH rats received a single i.p. injection of $1 \mathrm{ml}$ ascites containing $30 \mathrm{mg}$ of the monoclonal K14D10, M10H6 or an irrelevant monoclonal of identical isotype, respectively. The rats were killed $24 \mathrm{~h}$ later, serum was saved for detection of circulating mcICSA and the pancreas was immediately frozen in liquid nitrogen. The in vivo binding of the mc-ICSA on the islets was examined with the APAAP method described previously by direct incubation of the pancreatic cryosections with rabbit anti-mouse immunoglobulin and APAAP. Furthermore, the possible cytotoxic effects in vivo on Beta cells were examined in the NEDH rats after six i. p. injections of $1 \mathrm{ml}$ ascites per rat every second day. The animals were killed 5 days after the last application of mc-ICSA. For examination of specific Betacell destruction, pancreatic insulin and glucagon content were quantified by radioimmunoassay [8] for each animal loaded with mcICSA.

\section{${ }^{51} \mathrm{Cr}$ release assay for assessment of antibody-mediated cytotoxicity ( $A D C C$ and $C^{\prime} A M C$ ) in vitro}

The detection of antibody-dependent cellular cytotoxicity (ADCC) against rat islets in vitro was performed as detailed previously [20]. Briefly, 100 collagenase-isolated islets obtained from 6- 8-day-old rats were ${ }^{51} \mathrm{Cr}$-labelled by incubation in $200 \mu$ tissue culture medium RPMI 1640 supplemented with $10 \%$ heat-inactivated fetal calf serum and with $75 \mu \mathrm{Ci} \mathrm{Na}_{2}{ }^{51} \mathrm{CrO}_{4}$ (Institut für Kernforschung, Rossendorf, FRG) at $37^{\circ} \mathrm{C}$ for $1 \mathrm{~h}$. After washing five times by centrifugation, batches of five islets were incubated for $6 \mathrm{~h}$ at $37^{\circ} \mathrm{C}$ with $3 \times 10^{5}$ living mononuclear effector cells from a newly-diagnosed diabetic patient, in $100 \mu$ RPMI 1640 containing $50 \%$ hybridoma supernatant or diluted ascites fluid (1:20) containing islet cell reactive or irrelevant monoclonals. For determination of complementdependent antibody-mediated cytotoxicity (C'AMC) ${ }^{51} \mathrm{Cr}$-labelled neonatal rat islet cells were incubated with mc-ICSA containing culture supernatant or diluted ascites and 1:5 diluted rabbit complement as described previously [21]. The percentage of specific ${ }^{51} \mathrm{Cr}$-release was calculated:

specific ${ }^{51} \mathrm{Cr}-$ release $=\frac{{ }^{\mathrm{cpm}} \text { exp.release }{ }^{-\mathrm{cpm}} \text { spont.release }}{{ }_{\mathrm{cpm}} \text { max.release }} \times 100$

The mc-ICSA were considered to be islet-cell toxic if the ${ }^{51} \mathrm{Cr}$-release was greater than $\bar{x}+2$ SD as measured with irrelevant monoclonals. The spontaneous ${ }^{52} \mathrm{Cr}$-release of islets incubated with medium alone amounted to $8.77 \pm 0.51 \%$ ( $\bar{x} \pm$ SEM of 21 separate islet cell preparations). In addition, the monoclonals were tested for antilymphocyte C'AMC activity. In these experiments the ${ }^{51} \mathrm{Cr}$-release of splenic lymphocytes was estimated using the same protocol as described above.

\section{Statistical analysis}

Data are shown as means \pm SEM. Significant differences $(p<0.01)$ were determined with the Student's one-tailed $t$-test.

\section{Results}

The binding of monoclonal antibodies to RIN cells and islet sections is shown in Figure 1. Two stable hybridomas secreting monoclonal antibodies of the $\operatorname{IgG}_{2 \mathrm{~A}}$ isotype primary screened by CELISA were detected as cell surface antibodies by indirect fluorescence technique using the insulin-producing RIN cells as target (Fig. 1 a and b). Both monoclonals were confirmed as surface antibodies with a strong binding on normal living rat and mouse islet cells (ICSA). 

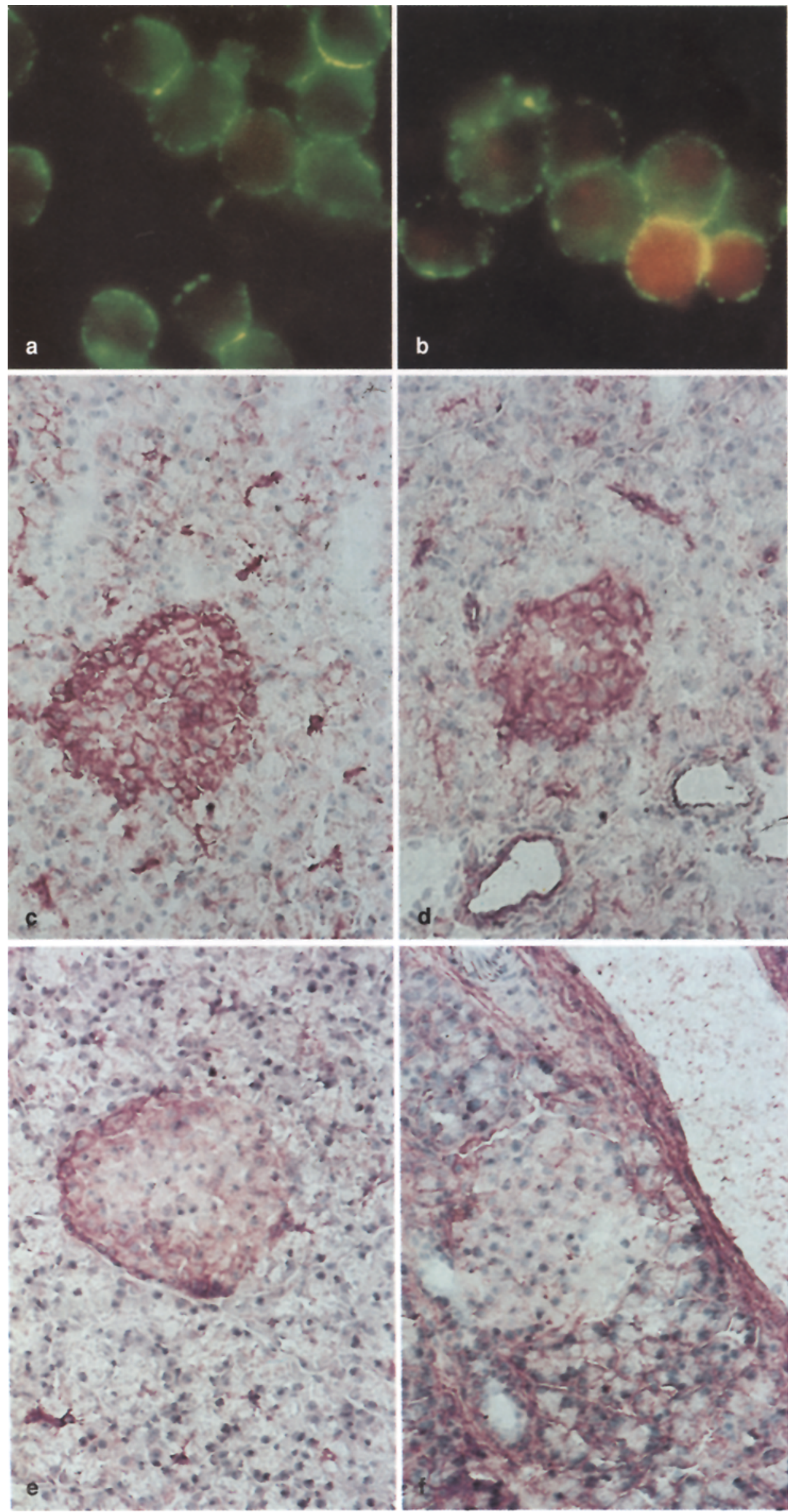

Fig.1a-f. Immunostaining of the surface of viable rat insulinoma cells by incubation with the monoclonal antibody M10H6 (a) and K14D10 (b) using the indirect immunofluorescence technique (magnification $\times 1500)$. Reactivity of the same antibodies M10H6 (c) and K14D10 (d) in vitro on islets of pancreatic cryosections of NEDH rats. The binding of $\mathrm{K} 14 \mathrm{D} 10$ (e) in the islets of NEDH rats in vivo was detected on pancreatic cryosections $24 \mathrm{~h}$ after application of $1 \mathrm{ml} \mathrm{K14D10}$ ascites immunostained by the use of alkaline phosphatase antialkaline phosphatase method (c-f; magnification $\times 250$ ). In spite of identical conditions, no in vivo islet binding was detectable for the monoclonal M10H6 (f) 


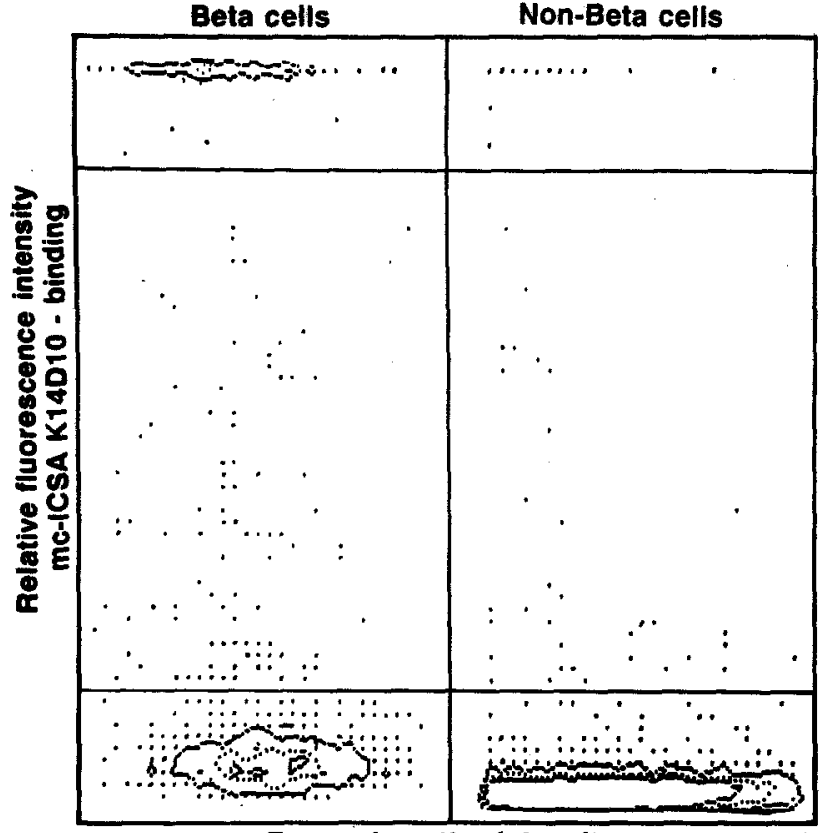

Forward scatter intensity

Fig. 2. Facstar-analysis of the monoclonal K14D10 binding to islet Beta and non-Beta cells purified from the rat pancreas. Each cell is plotted according to forward scatter intensity and rhodamine-associated fluorescence intensity. The left panel represents the Beta-cell surface binding. More than $14 \%$ of the Beta cells are recovered in the higher window. The right panel represents that less than $0.8 \%$ of the non-Beta cells are bound by K14D10 and recovered in the higher window, reflecting the Beta-cell specificity of this monoclonal relative to islet cells

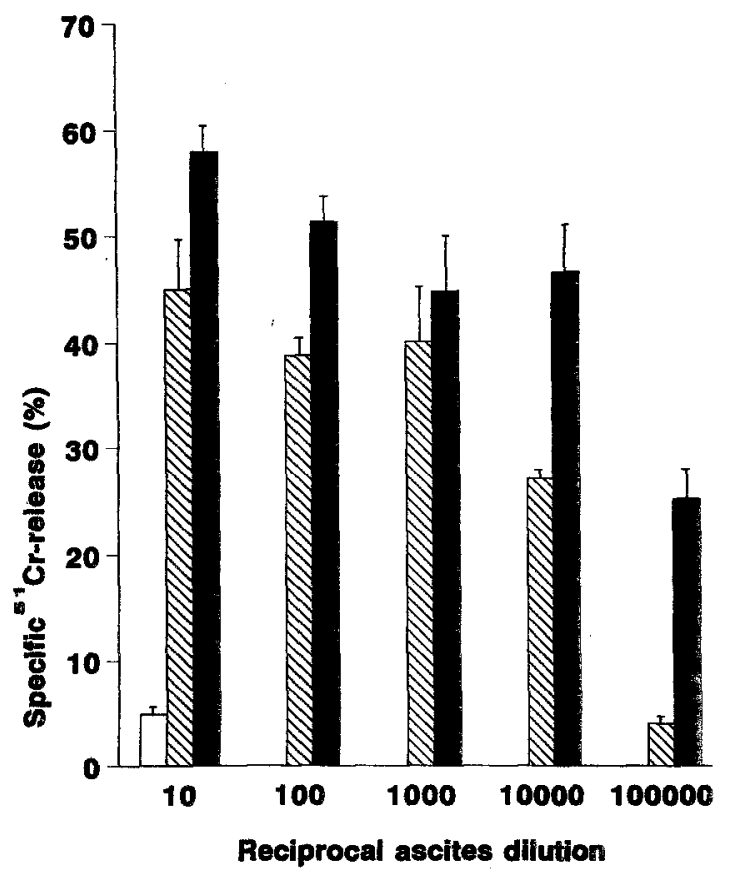

Fig. 3. Assessment of complement-dependent antibody-mediated cytotoxicity using ${ }^{51} \mathrm{Cr}$-labelled neonatal viable rat islet cells and rabbit complement. The specific ${ }^{51} \mathrm{Cr}$-release was measured in the presence of various ascites dilutions of the monoclonal islet cell surface antibodies M10H6 and K14D10 and of an irrelevant monoclonal $\square$ of the identical isotype $\operatorname{IgG}_{2 \mathrm{~A}}$. Data given as $\bar{x}+\operatorname{SEM}, n=3$
As shown by binding analysis in FACS on Beta and non-Beta islet cells both monoclonals preferentially recognised Beta cells. A typical antibody binding pattern of the monoclonal K14D10 on pre-sorted living rat islet cells is demonstrated in Figure 2.

Additionally, both monoclonal ICSA gave a typical ICA pattern on NEDH rat pancreatic cryosections (Fig. 1 c and d). The monoclonals did not cross react with insulin and glucagon when examined by radioimmunoassay.

By growing both antibody-producing hybridomas as ascites tumours in syngeneic mice, a high level of the monoclonals at a range of 20 to $50 \mathrm{mg} / \mathrm{ml}$ serum was also detectable in the circulation. However, the mice did not develop hyperglycaemia, and neither the pancreatic insulin/glucagon ratio nor the insulin content was diminished.

The ascites as well as the serum of the tumour bearing mice displayed a strong anti-rat islet cell toxicity in vitro, both in the presence of complement (C'AMC) (Fig.3) or $\mathrm{Fc}$-receptor bearing effector cells (ADCC) (Fig.4). Antiislet cytotoxicity was also mediated by mc-ICSA if rabbit serum was replaced by rat serum as complement source. Neither monoclonal mediated a cytotoxicity against lymphocytes $\left({ }^{51} \mathrm{Cr}\right.$-release $\left.1.4 \pm 0.2 \% ; n=6\right)$.

Both mc-ICSA were repeatedly injected into NEDH rats to evaluate their anti-Beta-cell toxicity in vivo; however, all animals remained normoglycaemic (plasma glucose $7.1 \pm 0.7 \mathrm{mmol} / 1 ; n=5$ ) and their pancreatic insulin content corresponded to those of rats receiving ir-

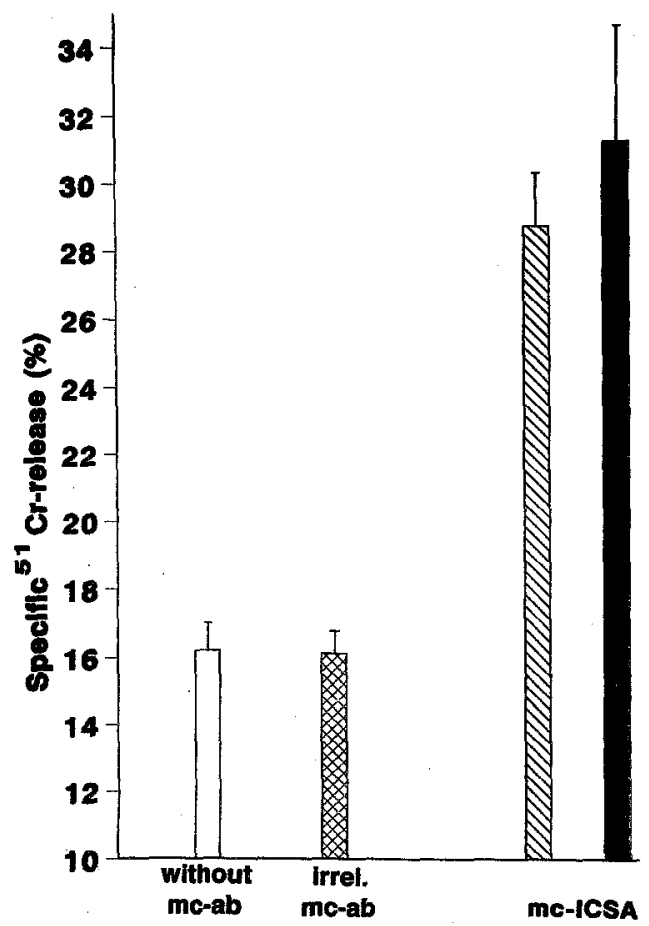

Fig.4. Assessment of antibody-dependent cellular cytotoxicity using ${ }^{51} \mathrm{Cr}$-labelled neonatal rat islets and mononuclear effector cells from a newly-diagnosed Type 1 (insulin-dependent) diabetic patient. The specific ${ }^{51} \mathrm{Cr}$-release was measured in the presence of the monoclonal islet cell surface antibodies M10H6 and K14D10 and of an irrelevant monoclonal of the identical isotype $\operatorname{IgG}_{2 \mathrm{~A}} \square$ as well as in the absence of a monoclonal Data given as $\bar{X}+S E M$ of three separate islet preparations 


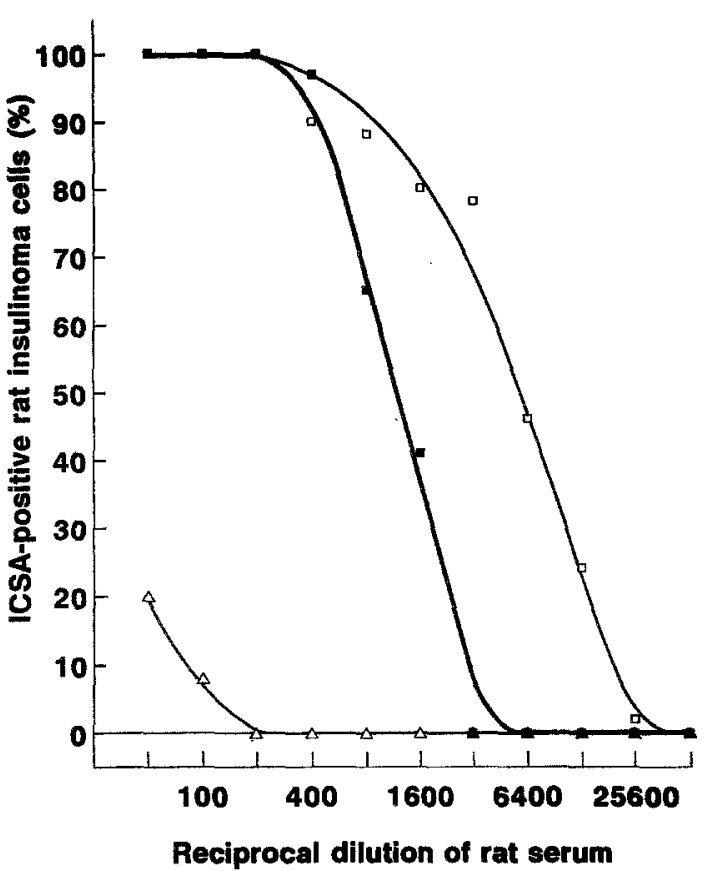

Fig. 5. Dependence of the percentage of rat insulinoma cell number with surface fluorescence on dilution of the NEDH rat serum of recipients received $24 \mathrm{~h}$ before $1 \mathrm{ml}$ ascites fluid of the islet cell surface antibodies K14D10 or M10H6 $\square$ and of an irrelevant monoclonal $\Delta$. Immunostaining of rat insulinoma cells was detected by indirect immunofluorescence technique

relevant antibodies $(27.4 \pm 1.7 \mathrm{pmol} / \mathrm{mg}$ pancreas vs $26.3 \pm 1.5 \mathrm{pmol} / \mathrm{mg}$ pancreas; $n=5$ in each group).

After injection of $1 \mathrm{ml}$ ascites of M10H6 or K14D10 into rats only K14D10 showed a binding on the islets as demonstrated by the cryosections of pancreas, whereas the mc-ICSA M10H6 with the same binding pattern in vitro was not detectable (Fig. $1 \mathrm{e}$ and $\mathrm{f}$ ) even though a high level of $\mathrm{M} 10 \mathrm{H} 6$ was detected in the circulation of recipient animals (Fig. 5).

\section{Discussion}

Whether the circulating islet cell reactive autoantibodies detectable before the clinical onset of Type 1 diabetes are involved in Beta-cell destruction is not yet clear. However, if any, only the Beta-cell surface reacting antibodies (ICSA) should be able to mediate Beta-cell damage by activation of the complement (C'AMC) or the Fc-receptor bearing cells (ADCC).

In this paper both the islet cell binding properties and the cytotoxic activity of two monoclonal ICSA (mcICSA) have been studied in vitro and in vivo. The mcICSA M10H6 was induced by immunization with RIN cells and after boostering with disintegrated rat islets, whereas, surprisingly, the K14D10 was obtained by an immortalized splenocyte from a mouse immunized by proinsulin. It is assumed that this antibody was induced secondarily after proinsulin antibody formation.

Independent of the different regimes used to establish primary induction the two monoclonals, $\mathrm{M} 10 \mathrm{H} 6$ and K14D10 showed striking surface binding to both the pri- mary rat islet cells and the insulin-producing RIN cells, which confirms similar results observed with other mcICSA $[13,22-25]$. The insulinoma cells obviously share many antigens of normal pancreatic islet cells and are suitable for detecting not only mc-ICSA but also polyclonal ICSA in Type 1 diabetic sera $[9,26,27]$. Neither of the two monoclonal ICSA are reactive with insulin and glucagon as tested by radioimmunoassay and both react preferentially with Beta cells as demonstrated by FACS analysis. There was no binding of the pre-sorted viable non-Beta cells by the monoclonal K14D10 compared to the Beta cells.

Interestingly, both surface antibodies react as ICA on rat pancreatic cryosections, which also means the monoclonal antibodies K14D10 and M10H6 recognize antigens which occur in the cytoplasm as well as on the surface of Beta cells. This dual reactivity as ICSA and ICA has been described previously by Eisenbarth et al. [28] for the mcICSA $\mathrm{A}_{2} \mathrm{~B}_{5}$, whereas most mc-ICSA failed to label the islets of pancreatic cryostat sections [23, 24]. Probably cell surface antigens are less abundant on pancreatic cryostat sections.

After injection of both mc-ICSA as well as an irrelevant monoclonal into NEDH rats only K14D10 was detectable in the islets of the cryosectioned pancreas although the antibody level of M10H6 in the circulation was higher than that of K14D10. This suggests that both mcICSA recognize different antigens as supported by significantly reduced $(50 \%)$ surface binding of M10H6 to trypsin-pretreated RIN cells whereas trypsin failed to affect RIN-cell binding of K14D10. Since the monoclonals belong to the same isotype of $\mathrm{IgG}_{2 \mathrm{~A}}$ it is suggested that an artifact due to different accumulation in the islets' capillaries should be excluded. Independent of the different in vivo accumulation of both the mc-ICSA in the islets there was no significant insulin loss seen after six i.p. injections of $1 \mathrm{ml}$ ascites per rat on every second day.

However, both mc-ICSA specifically mediated in vitro anti-rat islet cell toxicity in the presence of complement or Fc-receptor bearing effector cells. But no splenocytoxicity was mediated by the mc-ICSA, supporting the Beta-cell specific binding as detected by FACS analysis for islet cells. The lack of anti-islet toxicity of K14D10 in vivo despite high antibody level in the circulation, and striking islet cytotoxicity of these rat sera in vitro as in ascites supports the concept that ICSA-mediated activation of complement or of Fc-receptor-bearing cells alone is not sufficient to destroy the Beta cells. Alternatively these activations do not take place in vivo. Our results confirm data obtained by Pontesilli et al. [29] with an IgM monoclonal ICSA generated from a diabetic non-obese diabetic mouse. Although C'AMC against RIN cells was readily detected in the serum of the mice injected with the mcICSA, the mc-ICSA did not exert a diabetogenic action, even if injected into diabetes-prone mice [29]. The homologous species restriction of the complement-mediated lysis and the cytolytic inefficiency of murine serum can account for the lack of a diabetogenic action of mc-ICSA in the mice $[30,31]$.

Our results support the view that ICSA-mediated cytotoxicity to Beta cells plays only a minor role for Beta-cell destruction in the context of the cellular autoimmune 
mechanism causing Type 1 diabetes. This is shown by the ability of activated lymphocytes but not serum to transfer the diabetic syndrome of $\mathrm{BB}$ rats and non-obese diabetic mice $[32,33$. Nevertheless, the monoclonal antibodies reactive with Beta-cell antigens which are competitively inhibited in their antigen binding by antibody-positive serum from newly-diagnosed Type 1 diabetic patients remain an important tool for identifying and preparing antigens which are recognized by diabetes relevant autoantibodies. Some of these antigens may also be recognized by the immune effector cells which cause the Beta-cell destruction.

Acknowledgements. The authors acknowledge Dr. D.Pipeleers for the possibility of FACS analysis. We are greatful to Ms. D. Albrecht, H. Kenk, A.Schröder for excellent technical assistance and to Mr. G. Evans for language revision. This investigation was supported by the Grant Zi 407/1-1 from the Deutsche Forschungsgemeinschaft.

\section{References}

1. Gorsuch AN, Spencer KM, Lister J et al. (1981) Evidence for a long prediabetic period in type 1 (insulin-dependent) diabetes mellitus. Lancet II: 1363-1365

2. Baekkeskov S, Aanstoot HJ, Christgau S et al. (1990) Identification of the $64 \mathrm{~K}$ autoantigen in insulin-dependent diabetes as the GABA-synthesizing enzyme glutamic acid decarboxylase. Nature 347:151-156

3. Van de Winkel M, Smets G, Gepts W, Pipeleers D (1982) Islet cell surface antibodies from insulin-dependent diabetics bind specifically to pancreatic $\beta$-cells. J Clin Invest 70:41-49

4. Dobersen MJ, Scharff JE (1982) Preferential lysis of pancreatic B-cells by islet cell surface antibodies. Diabetes 31: $459-462$

5. Gazdar AF, Chick WL, Oie HK et al. (1980) Continuous, clonal, insulin- and somatostatin-secreting cell lines established from a transplantable rat islet cell tumor. Proc Natl Acad Sci USA 77: 3519-3523

6. Ziegler B, Kohnert KD, Noack S, Hahn HJ (1982) Effects of 3isobutyl-1-methylxanthine on secretory response, CAMP accumulation and DNA synthesis of islets from postnatal and adult Wistar rats. Acta Biol Med Germ 41: 1171-1177

7. Ziegler B, Hahn HJ, Ziegler M (1985) Insulin recovery in pancreas and host organs of islet grafts. Exp Clin Endocrinol 85: 53-60

8. Besch W, Woltanski KP, Keilacker H et al. (1987) Measurement of insulin in human sera using a new RIA kit. 1. Insulin determination in the absence of insulin antibodies - Conventional assay and micro modification. Exp Clin Endocrinol 90:264-270

9. Ziegler B, Heinke P, Schlosser M, Rjasanowski I, Michaelis D, Ziegler M (1989) Determination of islet cell surface antibodies in first-degree relatives of type 1 diabetic patients using rat insulinoma cells. Diab Res 12:25-29

10. Lane RD (1985) A short-duration polyethylene glycol fusion technique for increasing production of monoclonal antibodysecreting hybridomas. J Immunol Meth 81: 223-228

11. Witt S, Ziegler B, Blumentritt C, Schlosser M, Ziegler M (1991) Gewinnung monoklonaler Antikörper im serumfreien Kulturmedium mittels Dialysekultur. Allerg Immunol 37: 67-74

12. Witt S, Ziegler B, Ziegler M (1989) Detection of islet cell specificity of monoclonal islet cell surface antibodies by means of double-staining immunofluorescence. Acta Histochem 86: 111115

13. Ziegler B, Witt S, Waterstradt B, Schlosser M, Ziegler M (1989) Heterogeneity of monoclonal antibodies against pancreatic beta cells. Exp Clin Endocrinol 93: 173-180

14. Schlosser M, Witt S, Ziegler B, Ziegler M (1991) Influence of target cell preparation on binding of monoclonal islet cell reactive antibodies (mc-ICRA) in cellular enzyme linked immunosorbent assay (CELISA). J Immunol Meth 140; 101-109

15. Witt S, Ziegler B, Klöting I, Nadrowitz R, Schmidt W, Ziegler M (1987) Optimierung der Gewinnung muriner monoklonaler An- tikörper im Aszites syngener Mäuse durch einmalige Ganzkörperbestrahlung. Allerg Immunol 33: 259-264

16. Cordell I, Falini B, Erber WN et al. (1984) Immunoenzymatic labeling of monoclonal antibodies using immune complexes of alkaline phosphatase and monoclonal anti-alkaline phosphatase (APAAP complexes) J Histochem Cytochem 32:219

17. Ziegler M, DietzH, Keilacker H, Witt S, Ziegler B (1984) Monoclonal antibodies to human insulin and their antigen binding behaviour. Biomed Biochim Acta 43: 695-701

18. Van de Winkel M, Maes F, Pipeleers D (1982) Islet cell analysis and purification by light scatter and autofluorescence. Biochem Biophys Res Commun 107: 525-532

19. Vercammen M, Gories F, Foriers A et al. (1989) Cell surface antibodies in Type 1 (insulin-dependent) diabetic patients. I. Presence of immunoglobulins $M$ which bind to rat pituitary cells. Diabetologia 32: 611-617

20. Köhler E, Knospe S, Woltanski G et al. (1984) Antibody-dependent cell-mediated cytotoxicity of mononuclear cells against Langerhans islets of Wistar rats in normal man and in patients at diabetes risk. Biomed Biochim Acta 43: 627-633

21. Hehmke B, Lucke S, Schröder D, Klöting I, Kohnert KD (1990) Complement-dependent antibody mediated cytotoxicity in the spontaneously diabetic BB/OK rat: Association with $\beta$-cell volume density. Eur J Immunol 20: 1091-1096

22. Eisenbarth GS, Shimizu K, Bowring MA, Wells S (1982) Expression of receptors for tetanus toxin and monoclonal antibody A2B5 by pancreatic islet cells. Proc Natl Acad Sci USA 79: 50665070

23. Yokono K, Shii K, Hari J et al. (1984) Production of monoclonal antibodies to islet cell surface antigens using hybridization of spleen lymphocytes from nonobese diabetic mice. Diabetologia $26: 379-385$

24. Brogren CH, Hirsch F, Wood P, Druet P, Poussier P (1986) Production and characterization of a monoclonal islet cell surface autoantibody from the BB rat. Diabetologia 29:330-333

25. Ziegler M, Teneberg S, Witt $S$ et al. (1988) Islet $\beta$-cytotoxic monoclonal antibody against glycolipids in experimental diabetes induced by low dose streptozotocin and Freund's adjuvant. J Immunol 140: 4144-4150

26. McEvoy RC, Franklin BH, Gingsberg-Fellner F (1986) Biological differences in rat insulinoma cell line obtained from different laboratories do not affect binding of human anti-islet immunoglobulins. Diab Res 3: 339-344

27. Thomas JW, Virta VL, Nell LJ (1987) Cell surface antigens on rat islet tumors. J Immunol 138: 2896-2901

28. Eisenbarth GS, Walsh FS, Nirenberg M (1979) Monoclonal antibody to a plasma membrane antigen of neurons. Proc Natl Acad Sci USA 76: 4913-4917

29. Pontesilli O, Carotenuto P, Hayward AR, Prowse SJ (1989) A cytotoxic monoclonal islet cell surface antibody from the NOD mouse. J Clin Lab Immunol 28: 161-168

30. Shin ML, Häusch G, Hu WV, Nicholson-Weller A (1986) Membrane factors responsible for homologous species restriction of complement-mediated lysis: evidence for a factor other than DAF operating at the stage of C8 and C9. J Immunol 136: 1777-1782

31. Sassi F, Hugo F, Muhly M, Khaled A, Bhakdi S (1987) A reason for the cytolytic inefficiency of murine serum. Immunology 62 : 145-147

32. Koevary S, Rossini A, Stoller W, Chick W, Williams RM (1983) Passive transfer of diabetes in the BB/W rat. Science 220:727-728

33. Wicker LS, Miller BJ, Mullen Y (1986) Transfer of autoimmune diabetes mellitus with $\mathrm{T}$ cells from nonobese diabetic mice. Transplant Proc 28: 809-811

Received: 22 November 1991

and in revised form: 25 February 1992

Dr. B.Ziegler

Institute of Diabetes "Gerhardt Katsch"

Ernst-Moritz-Arndt-Universität Greifswald

O-2201 Karlsburg

FRG 